\title{
Game Simulasi Perakitan Rangkaian Elektronika Dasar Untuk Siswa Kelas X Berteknologi Mobile Augmented Reality
}

\author{
NENZA NURFIRMANSYAH ${ }^{1}$, REZKI YUNIARTI ${ }^{2}$, AGUS KOMARUDIN ${ }^{3}$
}

\author{
1,2,3]urusan Teknik Informatika, Fakultas Sains dan Informatika \\ Universitas Jenderal Achmad Yani \\ Jl. Terusan Jenderal Sudirman, Cimahi \\ Email : nnurfirmansyah@gmail.com
}

\begin{abstract}
ABSTRAK
Semakin tingginya mutu kurikulum yang akan dilaksanakan tentu harus diiringi dengan kebutuhan dengan standard mutu yang baik juga. Seringkali untuk pihak penyelenggara pendidikan sulit untuk menyediakan kebutuhan alat dan modul untuk menunjang pelajaran produktif, dengan harga yang mahal dan modul yang tidak selalu tersedia membuat siswa juga kesulitan untuk dapat belajar secara mandiri dengan keadaan tersebut. Game adalah salah satu media untuk dapat melakukan sesuatu hal dalam dunia nyata tanpa perlu memiliki peralatan nyatanya, seperti halnya education game dengan genre serious game yang telah dikembangkan sebagai media alternatif dalam bidang edukasi modern, diiringi teknologi Augmented Reality (AR) simulasi ini bisa dicapai dengan cukup baik. Maka, tujuan dari penelitian ini adalah merancang sebuah game edukasi dengan genre game simulasi yang dapat merepresentasikan kegiatan praktikum elektronika dasar oleh siswa Sekolah Menengah Kejuruan (SMK) sehingga siswa dapat belajar secara mandiri dengan lebih mudah dan biaya yang rendah untuk belajar dan mengurangi resiko kesalahan ketika melakukan praktikum secara langsung. Game dirancang dengan pendekatan Design Thinking dengan teknologi Mobile Augmented Reality (MAR) untuk mensimulasikan objek secara maya. Berdasarkan hasil evaluasi uji game melalui kuesioner pada siswa SMK jurusan Elektronika Komunikasi sebanyak 30 siswa, dimana aspek yang diuji terari dari latar belakang responden, interaksi dengan User Interface, dan User Experience yang didapatkan responden dari simulasi game menunjukkan bahwa rata-rata responden tertarik untuk melakukan perakitan elektronika dasar melalu game simulasi dengan skor $83,10 \%$ dan dapat menerima edukasi yang cukup baik melalu game tersebut dengan hasil ujian sebesar $79,16 \%$.
\end{abstract}

Kata kunci: Elektronika Dasar, Game Edukasi, Design Thinking, Augmented Reality(AR). 


\begin{abstract}
The increasingly high quality curriculum that will be implemented certainly has to be accompanied by needs with good quality standards as well. It is often difficult for the education provider to provide the need for tools to support practice, with high prices and modules that are not always available making it difficult for students to study independently in these circumstances. Game is one of the media to be able to do things in the real world without the need to have real equipment, such as education games with the genre of serious games that have been developed as alternative media of modern education, accompanied by Augmented Reality (AR) technology, This simulation can be achieved by pretty good. So, the purpose of this research is to design an educational game with a simulation game genre that can represent basic electronic practice by Vocational High School students so that students can learn independently more easily and lower costs and reduce the risk of errors when do practical work directly. The game is designed with the Design Thinking approach with Mobile Augmented Reality (MAR) to simulate virtual objects. Based on the results of the game test evaluation through a questionnaire on vocational students majoring in Communication Electronics as many as 30 students, where aspects were tested terari from the respondent's background, interaction with the User Interface, and User Experience obtained by respondents from game simulations showed that the average respondent was interested in doing basic electronics assembly through simulation games with a score of $83.10 \%$ and can receive a pretty good education through the game with $79.16 \%$ test results.
\end{abstract}

Keywords: Basic Electronics, Educational Games, Design Thinking, Augmented Reality $(A R)$. 
Game Simulasi Perakitan Rangkaian Elektronika Dasar Untuk Siswa Kelas X Berteknologi Mobile Augmented Reality

\section{PENDAHULUAN}

Peningkatan mutu kurikulum di sekolah memberikan dampak perubahan dalam pelaksanaannya yang menjadi semakin banyaknya kebutuhan dalam pendidikan atau sekolah yang diperlukan oleh siswa untuk dapat melaksanakan kegiatan tersebut. Kurikulum ini menjadi dasar kegiatan yang disusun oleh penyelenggara pendidikan dalam hal ini adalah Sekolah Menengah Kejuruan (SMK), dimana dalam Sekolah Menengah Kejuruan itu selalu ada kegiatan belajar normatif, adaftif, dan produktif.

Seringkali untuk pihak penyelenggara pendidikan sulit untuk menyediakan kebutuhan alat untuk menunjang pelajaran produktif, dengan harga yang mahal dan modul yang tidak selalu tersedia membuat siswa juga kesulitan untuk dapat membeli modul tersebut. Jika terjadi hal seperti itu maka kegiatan belajar akan terhambat dan siswa akan lebih sulit mengerti mata pelajar terkait.

Game menjadi salah satu media interaktif yang memberikan feedback antara pemain dan sistem secara cepat, lalu dengan adanya permainan simulasi maka proses belajar dengan tahapan penemuan, latihan, dan feedback lebih mudah untuk menyerap pengetahuan [1]. Game dengan basis simulasi dapat menjadi salah satu alternatif untuk proses belajar dan latihan untuk berbagai topik.

Pada game edukasi berbasis Android didapatkan bahwa game edukasi ini membantu baik guru dan siswa dalam mengubah cara belajar konvensional menjadi cara belajar simulasi [2]. Pada game edukasi sejarah walisongo berhasil dalam membantu guru untuk menyampaikan materi pembelajaran sesuai dengan kurikulum, dan user pun merasa lebih tertarik dalam mempelajari sejarah serta memberikan nuansa menyenangkan dalam belajar [3]. Pada penelitian lain membahas pembelajaran menggunakan game simulasi Sim City 4 menghasilkan suasana kelas lebih hidup, 52\% siswa setuju untuk menggunakan game simulasi karena penggunaan media Sim City 4 dapat diterima oleh siswa, hasil oleh data menunjukkan bahwa rata-rata nilai kognitif siswa sebesar $66,25 \%$ yang artinya game simulasi ini efektif dalam meningkatkan nilai kognitif siswa [4].

Untuk merancang game sebuah game terdapat beberapa komponen utama salah satunya yaitu goal dari game tersebut. Untuk mencapai goal tersebut maka digunakan metode perancangan yang tepat seperti metode design thinking dimana metode ini mengfokuskan hasil sesuai dengan kebutuhan user. Design thinking memberikan tingkat keberhasilan yang tinggi untuk mencapai goal dengan melalui tahapannya yaitu discovery, interpretation, ideation, experiment, dan evolution [5]. Pada game MINECRAFT yaitu game simulasi bertahan hidup menggunakan pendekatanan goal-setting theory menghasilkan kinerja maksimal untuk pemain mendapatkan pengalaman yang sama seperti dunia nyata, dari sini game simulasi dapat diambil sisi edukasinya jika game simulasi memenuhi targetnya [6] pendekatan goalsetting theory ini mengefektifkan penggunaan design thinking pada pembuatan sebuah game simulasi sehingga mendapatkan hasil yang sama seperti kebutuhan target. Dalam hal ini pencapaian akademik secara tradisional dapat lebih dicapai secara luas dengan game simulasi [7] penelitian ini menyebutkan dengan dua cabang ilmu yaitu design siences dan analytical sciences game simulasi yang baik dapat dibuat untuk mencapai hal tersebut.

\section{STUDI PUSTAKA}

\subsection{Game Edukasi}

Metode mengajar dengan menyajian pengalaman belajar yang sama dengan objek nyatanya dapat disampaikan melalui media simulasi digital, game dapat dimanfaatkan sebagai media 
pembelajaran dalam proses belajar mengajar yang dapat membangkitkan keinginan dan minat baru pada siswa [8]. Game simulasi ini dapat disematkan beberapa edukasi bagi penggunanya, yang merupakan genre yang dapat dibuat menjadi dunia virtual dan dapat memiliki nilai edukasi [9]. Game edukasi merupakan permainan digital yang dapat memberikan kesempatan untuk bermain melalui lingkungan simulasi dan dapat menjadi bagian integral dari pembelajaran dan pengembangan intelektual [10]. Game edukasi dapat dibuat dengan genre simulasi yang akan merepresentasikan seperti kejadian di dunia nyata yang dapat membantu masyarakat dalam pembelajaran yang tidak membosankan.

\subsection{ELEKTRONIKA}

Elektronika merupakan ilmu yang mempelajari alat listrik arus lemah yang dioperasikan dengan cara mengontrol aliran elektron atau partikel bermuatan listrik dalam suatu alat seperti komputer, peralatan elektronik, termokopel, semikonduktor, dan lain sebagainya. Berbagai komponen-komponen berkembang dari segi efisiensi, fungsi, manfaat dan maupun fisik.

Dalam Elektronika teradapat beberapa cabang utama diantaranya elektronika analog, elektronika digital, mikroelektronik, rangkaian terintegrasi (IC), optoelektronik, dan semikonduktor [11].

\subsection{Human Computer Interaction}

Human Computer Interaction ( $\mathrm{HCI}$ ) atau dalam bahasa Indonesia Interaksi Manusia dan Komputer adalah disiplin ilmu yang mempelajari tentang sistem komputer interaktif untuk kegunaan manusia yang menekankan pada aspek desain, evaluasi, dan implementasi dengan mempertimbangkan hal-hal disekitar manusia itu sendiri. Dengan disiplin ilmu ini maka dapat membantu bagaimana membuat desain aplikasi yang sesuai untuk pengguna dan nyaman dalam penggunaannya.

Pada penelitian First Time User Experiences in mobile games : An evaluation of usability [12] didapatkan bahwa desain secara intuitif dan model interaksi antara manusia dengan komputer sangat penting untuk penggunaan. Dengan bimbingan atau arahan interaksi yang baik maka akan mempermudah bagaimana membuat desain aplikasi yang sesuai.

\subsection{Design Thinking}

Design Thinking adalah salah satu metode baru dalam melakukan proses desain. Design Thinking merupakan metode penyelesaian masalah yang berfokus pada pengguna atau user [13]. Design Thinking sendiri dipopulerkan oleh David Kelley dan Tim Brown pendiri IDEO sebuah konsultan desain yang berlatar belakang desain produk berbasis inovasi.

Design Thinking memiliki beberapa elemen penting yaitu :

1) People centered : dalam metode ini, perlu ditekankan bahwa setiap tindakan yang dilakukan berpusat pada apa yang diinginkan dan dibutuhkan oleh user.

2) Highly creative : dalam menggunakan metode ini, dapat digunakan kreativitas sebebasnya, tidak perlu aturan yang terlalu kaku dan baku.

3) Hands on : proses desain memerlukan percobaan langsung oleh tim desain, bukan hanya pembuatan teori atau sebuah gambaran di kertas. 
4) Iterative : proses desain merupakan sebuah proses dengan tahapan-tahapan yang dilakukan berulang-ulang untuk melakukan improvisasi dan menghasilkan sebuah produk atau aplikasi yang baik.

\section{GAME SIMULASI DAN MOBILE AUGMENTED REALITY}

\subsection{Game Simulasi}

Game adalah permainan terdiri atas sekumpulan peraturan yang membangun situasi bersaing dari dua sampai beberapa orang atau kelompok dengan memilih strategi yang dibangun untuk memaksimalkan kemenangan sendiri ataupun untuk meminimalkan kemenangan lawan [12]. Game atau permainan adalah sesuatu yang dapat dimainkan dengan aturan tertentu sehingga ada yang menang dan ada yang kalah, biasanya dalam konteks tidak serius dengan tujuan refreshing [13].

\subsection{Augmented Reality}

Teknologi Augmented reality merupakan salah satu trobosan yang digunakan pada akhir-akhir ini di dibidang interaksi. Penggunaan teknologi ini akan sangat membantu dalam menyampaikan suatu informasi kepada pengguna. Augmented reality merupakan teknologi interkasi yang menggabunngkan antara dunia nyata (real world) dan dunia maya (virtual world) [14]. Tujuan dalam penggunaan teknologi augmented reality ini adalah menambahkan pengertian dan informasi pada dunia nyata dimana sistem Augmented Reality mengambil dunia nyata sebagai dasar dan menggabungkan beberapa teknologi dengan menambahkan data kontekstual agar pemahaman seseorang menjadi jelas [15]. Augmented Reality memiliki tiga karakteristik yang menjadikan dasar pembuatannya yaitu kombinasi dunia nyata dan dunia virtual, berjalannya interaksi secara real-time, dan model 3D.

Mobile Augmented Reality adalah teknologi Augmented Reality yang dapat diakses oleh perangkat smartphone sehingga memudahkan penggunaan bagi pengguna maupun pengembang. Teknologi ini digunakan pada perusahaan inovatif sebagai salah satu pendukung termudah dalam Augmented Reality. Keuntungan lain adalah bahwa perangkat mobile terbaru sekarang dilengkapi dengan fitur tambahan seperti Global Positioning System (GPS), kamera dengan spesifikasi tinggi, Bluetooth, audio/video pemain, anemometers, dan perangkat sensorik lainnya [16]. Banyak smartphone, seperti iPhone dan Android, sudah mampu untuk menerapkan Mobile Augmented Reality (MAR).

MAR ini memerlukan marker untuk memunculkan objek tertentu sesuai dengan objek yang disediakan pada aplikasi terkait, marker ini dapar disematkan pada sebuah kertas yang dicetak sendiri ataupun dari kartu yang biasanya disediakan dari developer augmented reality.

\subsubsection{Komponen Mobile Augmented Reality}

Beberapa komponen yang diperlukan dalam pembuatan dan pengembangan aplikasi AR adalah sebagai berikut :

\section{a. Komputer.}

Komputer berfungsi sebagai perangkat yang digunakan untuk mengendalikan semua proses yang akan terjadi dalam sebuah aplikasi. Penggunaan komputer ini disesuaikan dengan kondisi dari aplikasi yang akan digunakan. Kemudian untuk output aplikasi akan ditampilkan melalui monitor.

b. Marker.

Marker berfungsi sebagai gambar (image) dengan warna hitam dan putih dengan bentuk persegi. Dengan menggunakan marker ini maka proses tracking pada saat aplikasi digunakan. 
Komputer akan mengenali posisi dan orientasi dari marker dan akan menciptakan objek virtual yang berupa obyek 3D yaitu pada titik $(0,0,0)$ dan 3 sumbu $(X, Y, Z)$.

\section{c. Kamera.}

Kamera merupakan perangkat yang berfungsi sebagai recording sensor. Kamera tersebut terhubung ke komputer yang akan memproses image yang ditangkap oleh kamera. Apabila kamera menangkap image yang mengandung marker, maka aplikasi yang ada di komputer tersebut mampu mengenali marker tersebut. Selanjutnya, komputer akan mengkalkulasi posisi dan jarak marker tersebut. Lalu, komputer akan menampilkan objek 3D di atas marker tersebut.

\section{METODE PENELITIAN}

Merujuk pada Gambar 1, penelitian ini terbagi menjadi lima tahap proses, yaitu tahap Empathise yang akan dilaksanakan dengan melakukan observasi lapangan dan wawancara, tahap Define merupakan tahapan mendefinisikan masalah yang terjadi pada pengguna, tahap Ideate mendefinisikan solusi dari permasalahan, tahap Prototype membuat produk awal yang menyerupai hasil akhir, Tahap Test melakukan uji coba secara langsung hasil akhir produk kepada pengguna. Metode Design Thinking akan dilakukan dengan satu kali iterasi yang akan berakhir pada satu kali pengujian.

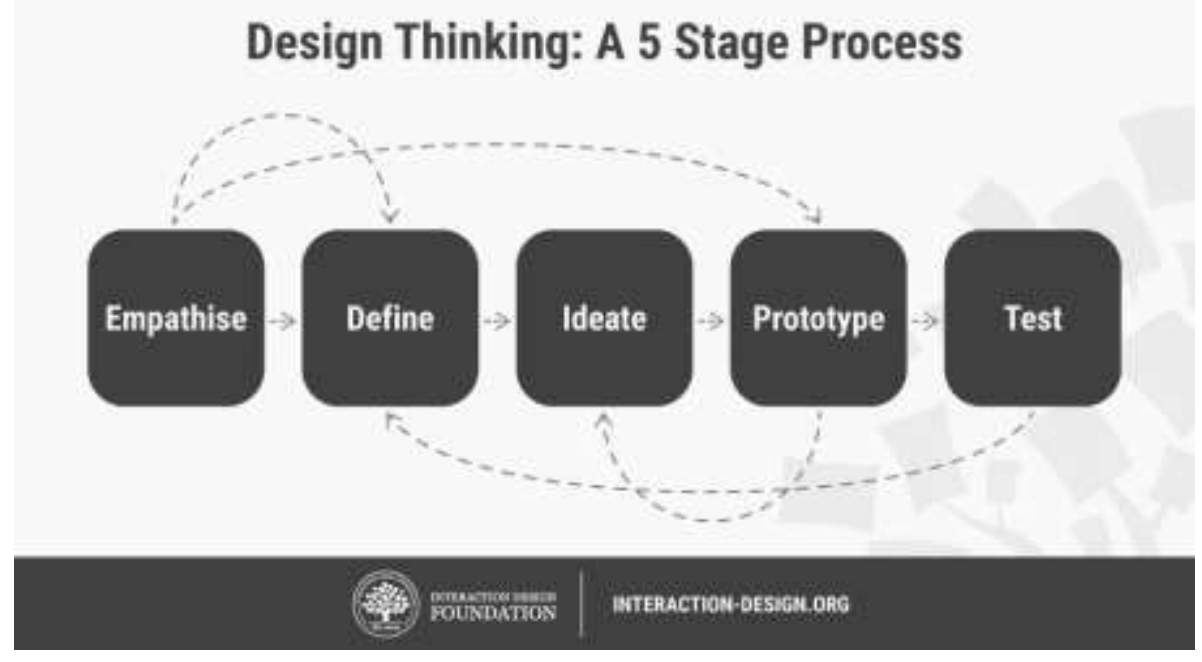

Gambar 1. Design Thinking (Interaction-Design.org)

\subsection{Empathise}

Pada tahap ini, melakukan observasi langsung pada sekolah yang berkaitan untuk melihat kegiatan belajar dan melakukan wawancara pada siswa dan guru yang mengajar. Tahapan ini perlu dilakukan guna untuk memperoleh informasi tentnag bagaiman pandangan siswa dan guru tentang cara belajar yang efektif untuk mata pelajaran yang berkaitan.

\subsection{Define}

Pada tahapan ini, mengumpulkan seluruh informasi yang telah didapat dari hasil observasi dan wawancara yang telah dilakukan yang menghasilkan definisi permasalahan yang terjadi di lapangan. Contohnya bagaimana cara untuk meningkatkan minat belajar dari siswa untuk mata pelajaran elektronika dasar.

\subsection{Ideate}

Pada tahapan ini dilakukan pencarian ide sebagai solusi untuk mengatasi masalah yang terjadi dilapangan. Solusi yang diberikan berupa game edukasi dengan jenis game simulasi dengan 
teknologi Mobile Augmented Reality sehingga skenario yang terjadi di dalam game merepresentasikan seperti kejadian nyata (real life). Tahapan ini akan melakukan perancangan game, bagaimana skenario game akan dilakukan dan cara kerja game tersebut seperti apa. Game ini akan dibuat dengan berdasarkan skenario praktikum mata pelajaran terkait. Pemain dapat mengikuti skenario yang telah disediakan oleh game dan juga dapat mengikuti modul praktikum. Pemain dapat menggerakan peralatan pada lewat smartphone atau dengan menggerakkan marker.

\subsection{Prototype dan Pembuatan Asset}

Tahapan ini dilakukan membuat komponen pembuatan asset game yang diperlukan, pengembangan game yang akan dibuat, dan melakukan pengujian rancangan awal game yang telah dibuat, tujuan tahapan ini adalah menyesuaikan skenario game dengan skenario praktikum yang dilakukan di dunia nyata. Pengujian ini dilakukan untuk mendapatkan users goal dalam mendapatkan pengalaman yang sama dengan kegiatan nyata.

\subsection{Pengujian Sistem}

Setelah melakukan pengembangan dilakukan pengujian sistem yang telah dibuat dengan mencoba system yang telah dibuat kepada siswa untuk mendapatkan respon hasil user experience yang didapatkan ketika siswa bermain game.

\subsection{Dokumentasi Dan Publikasi IImiah}

Seluruh tahapan, proses penelitian dan hasil kesimpulan akan dimasukkan dalam bentuk laporan. Laporan penelitian akan disusun sesuai dengan ketentuan pedoman penulisan standar nasional.

\section{IMPLEMENTASI DESIGN THINKING}

\subsection{Empathise}

Pada tahapan awal ini dilakukan pengambilan data dengan cara observasi langsung tempat penelitian dan wawancara kepada pihak yang bersangkutan yaitu guru mata pelajaran elektronika dasar. Pengambilan data dan observasi ini dilakukan pada siswa kelas X (sepuluh) pada jurusan Elektronika Komunikasi yang berjumlah 2 kelas, masing-masing kelas tersebut memiliki siswa 30 orang. Menurut Sugiyono observasi ini dilakukan dengan 3 tahap yaitu Deskripsi, Reduksi, dan Seleksi [17]. Secara detail data observasi yang diambil berdasarkan tahapan tersebut adalah :

1) Deskripsi : Siswa kelas X SMK Negeri 1 Cimahi Jurusan Elektronika Komunikasi

2) Reduksi : Mata pelajaran Elektronika Dasar siswa kelas $X$

3) Seleksi : Praktikum perakitan rangkaian Elektronika Dasar

Pengambilan data pada siswa dilakukan dua tahap dengan memberikan kuisioner yaitu kuisioner sebelum pengujian, dan kuisioner setelah pengujian. Dua tahapan ini dilakukan untuk mengetahui kebutuhan user dalam pembangunan game edukasi. Tahapan pertama dilakukan untuk mengetahui bagaimana tingkat pengetahuan user pada ide perangkat yang akan dibangun dan untuk mengetahui kebutuhan user yang diinginkan sehingga pengalaman user tercapai sesuai ekspektasi, lalu tahapan kedua dilakukan feedback dari user untuk mengetahui apakah game tersebut sudah sesuai kebutuhan atau belum. 


\subsection{Define}

Dalam metode Design Thinking tahapan yang kedua adalah Define dimana pada tahapan ini diharuskan mengumpulkan informasi dari hasil tahap Empathise yaitu melakukan wawancara dan observasi lapangan sehingga dapat memperlihatkan hasil permasalahan yang terjadi. Pada kasus ini masalah yang diambil adalah dalam praktikum elektronika dasar atau bisa disebut sebagai kelas produktif mata pelajaran elektronika dasar dan alat ukur.

Aspek umum tersebut memiliki hubungan dalam pelaksanan praktikum elektronika dasar dalam hal merangkai rangkai elektronika, dan hal ini akan menghasilkan sebuah output atau hasil belajar yang berbeda dengan yang diharapkan oleh staff pengajar. Maka dari itu dibutuhkan sebuah pola pembelajaran yang baru dan interaktif untuk mengoptimalkan kegiatan belajar dan implementasi praktikum yang lebih efisien dengan bantuan teknologi Mobile Augmented Reality sehingga beberapa permasalahan di atas dapat dikurangi.

\subsection{Ideate}

Tahap Ideate dimana pada tahap ini dilakukan analisa kebutuhan user untuk menyelesaikan masalah yang terjadi. Perlu disediakan beberapa alternatif yang dapat ditawarkan kepada user atau disediakan dengan kesepakatan bersama. Terdapat beberapa alternatif yang dapat dilakukan berdasarkan dari hasil wawancara dan melihat dari permasalahan yang terjadi untuk menyelesaikan masalah dalam proses belajar. Berikut beberapa alternatif yang tersedia dari hasil analisis masalah yang didapatkan, diantaranya :

1) Pembelajaran multimedia, pemanfaatan mobile device

2) Game edukasi, untuk membuat challenge yang sesuai

3) Visualisasi 3D, untuk mengurangi penggunaan komponen asli

Beberapa alternatif yang tersedia diambil berdasarkan teknologi yang akan digunakan yaitu Mobile Augmented Reality sehingga alternatif tersebut lebih diarahkan kepada pembelajaran multimedia, dalam hal ini pembelajaran multimedia akan disajikan dalam bentuk Game Simulasi. Genre simulasi diambil karena penyajian dalam game tersebut memerlukan pendekatan dengan aspek dunia nyata, dan cara bermainnya sebisa mungkin mirip dengan dunia nyatanya.

\subsection{Prototype}

Tahapan ini dilakukan untuk memperlihatkan versi awal sistem yang telah dibuat kepada user, versi awal ini masih berupa tampilan sederhana dari keseluruhan sistem yang akan dibangun.

\subsection{Pengaturan Game}

Game ini akan dibangun dengan resolusi 1280 x 720 dengan posisi fix landscape right, sehingga tidak dapat diubah menjadi portrait atupun landscape left. Dikarena menggunakan teknologi Augmented Reality maka posisi kamera adalah First Person pada kamare device yang digunakan. 


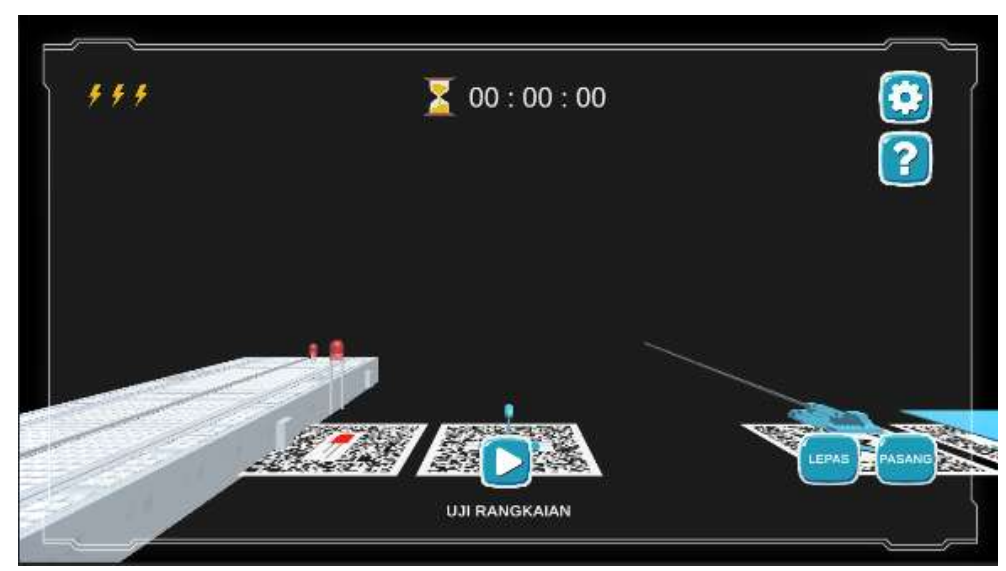

\subsection{Skenario Permainan}

Gambar 2. Tampilan Kamera AR

Skenario permainan dibangun dengam beberapa fitur untuk membantuk pemain menyelesaikan game. Skenario dan fitur-fitur yaitu sebagai berikut.

\subsubsection{Menu Utama}

Pada saat permainan dijalankan maka game akan menampilkan menu utama. Menu utama memiliki beberapa tombol menu, diantaranya:

1) Start Game yaitu tombol untuk memulai simulasi merakit ketika praktikum dimulai. Pemain akan diarahkan ke pemilihan level saat menekan tombol ini.

2) Tutorial yaitu tombol untuk memulai bantuan bermain pada menu ini akan dijelaskan cara bermain

3) Exit yaitu tombol untuk keluar dari permainan.

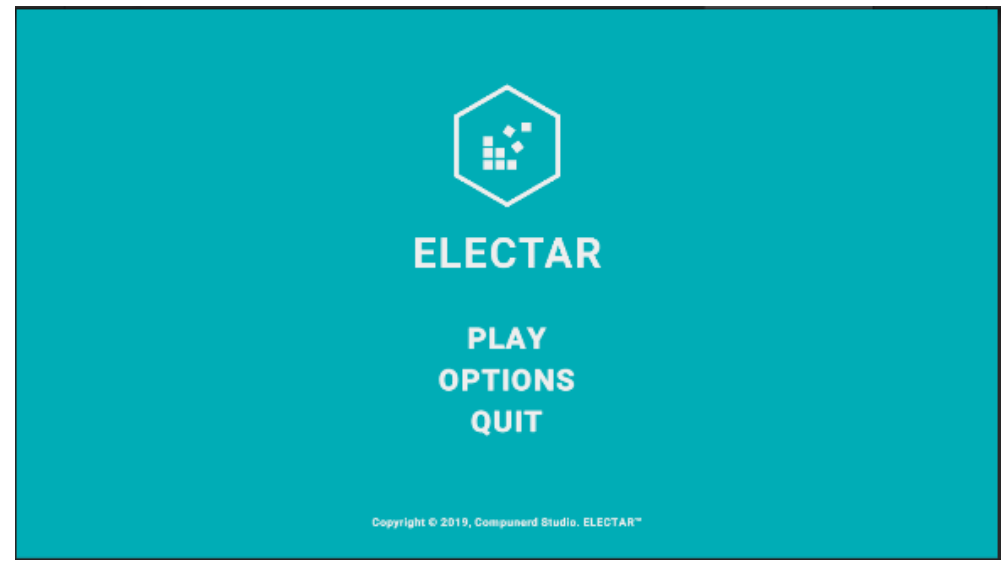

Gambar 3. Tampilan Menu Utama

\subsubsection{Tutorial Game}

Pada tutorial pemain akan diberikan proses learning atau belajar kontrol dasar untuk mengendalikan objek dan pengenalan komponen serta pengaturan komponen yang digunakan.

a. Pada awal tutorial pemain akan diberikan petunjuk cara menggunakan teknologi Augmented Reality seperti pengenalan marker dan perangkat yang digunakan. Selain cara menggunakan terdapat juga petunjuk untuk menggunakannya. 
b. Pemain akan diberikan pentunjuk tentang informasi yang ditunjukkan pada layar seperti, chance point, time, dan score.

c. Pemain diberikan petunjuk tentang informasi aksi yang terdapat pada layar seperti, ambil/lepas objek, pasang objek, uji coba rangkaian.

d. Setelah melewati tutorial dasar pemain dapat melanjutkan ke proses belajar menentukan nilai komponen.

e. Pemain diberikan petunjuk tentang informasi aksi yang terdaapat pada layar seperti tentukan warna resistor untuk mengubah nilai resistor.

\subsection{Ringkasan Gameplay}

Gameplay dalam game simulasi ini adalah pemain harus merakit rangkaian elektronika sederhana yang jalur rangkaiannya telah disediakan, setiap level memiliki tingkat kesulitan yang berbeda.

\subsection{Key Game Mechanic}

Key Game Mechanic merupakan penggerak pada game dan menjadi poin penting dalam menentukan kondisi menang atau kalahnya pemain dalam game. Terdapat empat key utama dalam game ini, antara lain :

a. Chance Point: Chance Point merupakan kesempatan bermain pada pemain untuk dapat melakukan perakitan rangkaian elektronika, setiap pemain memiliki tiga chance point.

b. Time : Time merupakan waktu yang disediakan untuk bermain disetiap levelnya, jika waktu habis maka akan mengurangi chance point pemain dan pemain harus mengulangi permainan dari permulaan level tersebut. Waktu tidak dapat bertambah dan waktu akan ditentukan sesuai dengan levelnya.

c. Tutorial : Tutorial merupakan bagian latihan untuk pemain sebagai pentunjuk untuk dapat memainkan permainannya, tutorial ini ditunjukkan pada masing-masing level yang berbeda sehingga pemain dapat melakukan permainan sesuai dengan tutorial yang ditunjukkan.

\subsection{Kondisi Menang}

Kemenangan akan didapatkan jika pemain sudah menempatkan seluruh komponen dengan benar, lalu menguji coba rangkaian tersebut hingga tidak terjadi kesalahan dalam rangkaian dan akan mendapatkan score berdasarkan waktu penyelesaiannya.

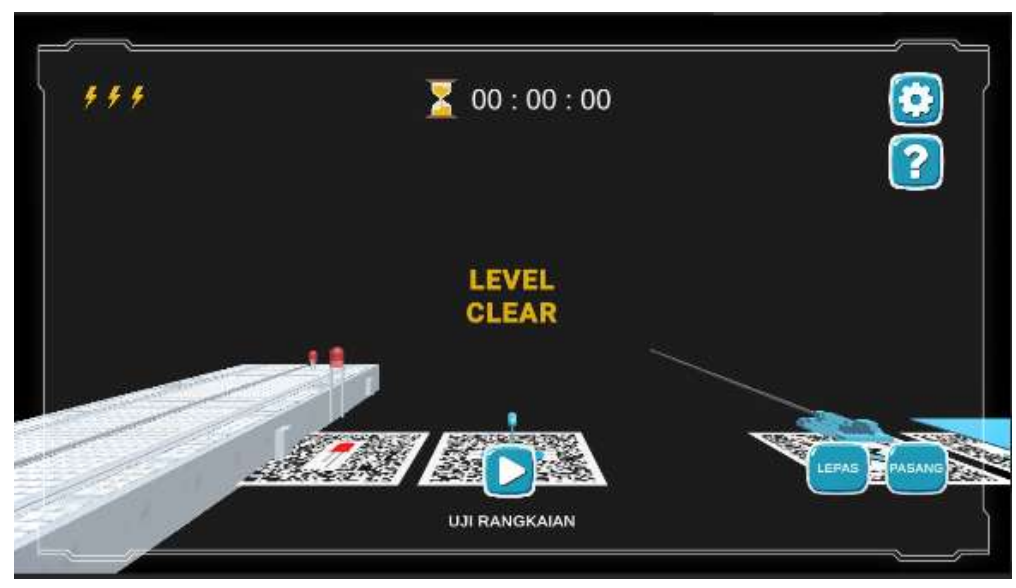

Gambar 4. Tampilan Kondisi Menang 


\subsection{Kondisi Kalah}

Pada game simulasi ini terdapat Chance Point atau kesempatan untuk melakukan percobaan perakitan, Chance Point ini akan berkurang jika terjadi kegagalam perakitan atau kesalahan dalam penempatanan komponen elektronika. Kekalahan akan didapatkan jika Chance Point habis atau telah nol. maka permainan berakhir pada level tersebut.

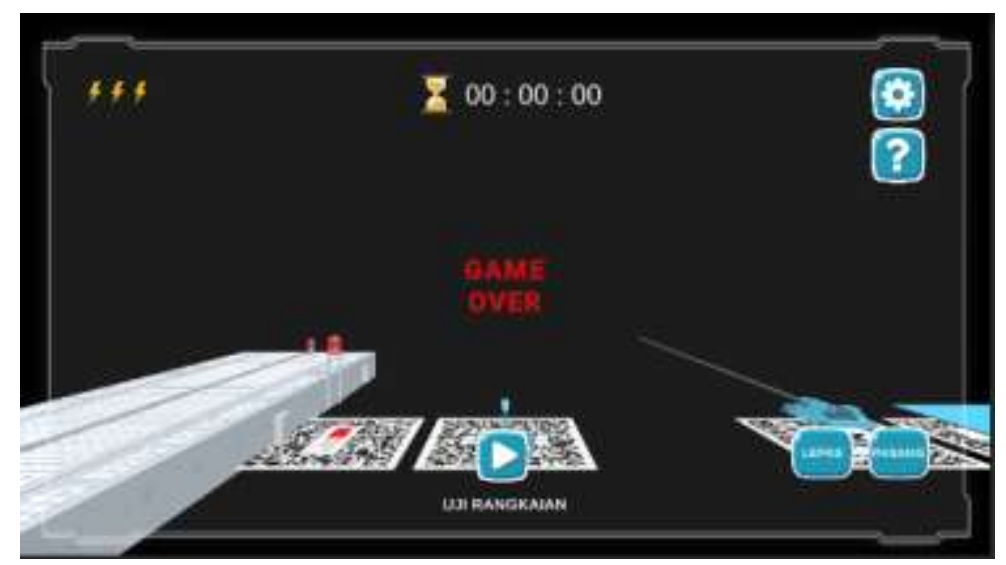

\section{Gambar 5. Tampilan Kondisi Kalah}

\subsection{Game Mekanik}

Mekanik pada game ini adalah dengan menggunakan Controller pada layar smartphone, digunakan untuk gerak dasar dan aksi dasar yang bisa dilakukan oleh objek. Gerak dasar yang bisa dilakukan oleh objek adalah berpindah posisi. Untuk aksi dasar yang bisa dilakukan oleh objek adalah disimpan sesuai posisi pada objek lain. Luas gerakan objek adalah seluas arena game yang telah terdeteksi oleh smarphone pada objek marker yang telah dipindai seluas resolusi layar smarphone yaitu 1280 x 720. Posisi kamera adalah First Person Camera sehingga kamera berada pada tangan pengguna langsung, kamera adapat digerakkan dengan menggerakkan smartphone pemain.

Saat objek telah dipilih, objek dapat dipindahkan sesuai dengan posisi jari memindahkan objek tersebut. Objek akan menjadi kecil ketika ditempatkan di posisi yang jauh dari posisi seharusnya dan akan membersar jika didekatkan ke kamera smarphone. Tombol pasang dan lepas berukuran $75 \times 75$ pixel ditempatkan dibawah kanan layar. Tombol lepas berada di atas tombol pasang dengan jarak antar tombol 20 pixel.

\subsection{Tingkat Kesulitan}

Game ini akan dibuat 3 level secara berurutan, pemain akan mendapatkan pengalaman bermain dan tingkatan edukasi yang bebeda, karena setiap levelnya memiliki tingkat kesulitan yang berbeda. Kesulitan yang terjadi pada game ini juga karena Chance Point tidak dapat dipulihkan jika terjadi pengurangan dan permaian tidak bisa ditunda selama berlangsung, hal ini bertujuan agar pemain dapat fokus mengerjakan tantangan sebagai simulasi dari praktikum yang dijelaskan.

\subsection{Desain Objek}

Pada game ini terdapat tiga objek yang dapat dipindai menggunakan marker yang tersedia dan setiap objek ini dapat berinteraksi agar rangkaian dapat berfungsi. Marker yang dapat dipindai dapat dilihat pada Tabel 1. 
Tabel 1. Objek dalam Game

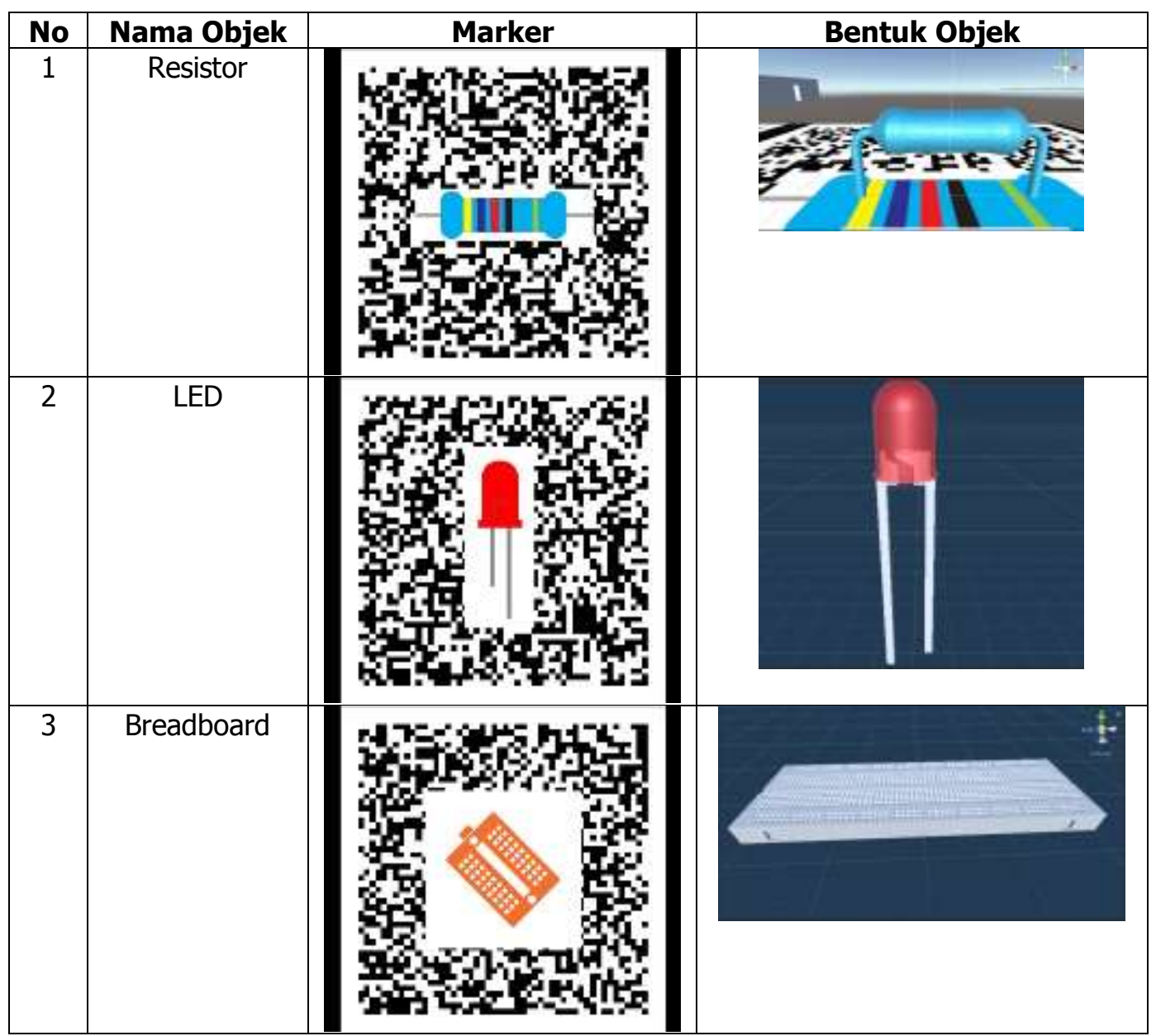

6. HASIL EVALUASI

Pengujian dilakukan terhadap 30 orang responden. Pengujian dilakukan dengan memainkan game ELECTAR. Setelah game tersebut dimainkan, para responden mengisi kuesioner yang memuat pertanyaan mengenai tanggapan setelah memainkan game ELECTAR.

Penghitungan hasil tanggapan kesioner dihitung menggunakan skala Likert. Berdasarkan hasil kuesioner kriteria kesesuaian aspek di dalam game dibagi menjadi lima, yaitu:

$$
\begin{aligned}
& \text { 1. } 00,00-19,00=\text { Sangat tidak sesuai } \\
& \text { 2. } 20,00-39,99=\text { Tidak sesuai } \\
& \text { 3. } 40,00-59,99=\text { Cukup sesuai } \\
& \text { 4. } 60,00-79,99=\text { Sesuai } \\
& \text { 5. } 80,00-100=\text { Sangat sesuai }
\end{aligned}
$$

Rentan nilai sebesar 20 bedasarkan rumus Likert dimana $100 \%$ dibagi dengan jumlah opsi penilaian. 
Tabel 2. Hasil Penelitian

\begin{tabular}{|c|c|c|c|c|c|}
\hline No & $\begin{array}{c}\text { Aspek } \\
\text { Penilaian }\end{array}$ & Pertanyaan & Skor & Rata-rata & Kriteria \\
\hline \multirow[t]{6}{*}{1} & \multirow{6}{*}{$\begin{array}{l}\text { Latar } \\
\text { belakang } \\
\text { pemain }\end{array}$} & Saya senang elektronika & 82,66 & - & $\begin{array}{l}\text { Sangat senang } \\
\text { elektronika }\end{array}$ \\
\hline & & $\begin{array}{l}\text { Saya tertarik merakit } \\
\text { rangkaian elektronika }\end{array}$ & 80,00 & - & $\begin{array}{c}\text { Sangat tertarik } \\
\text { merakit } \\
\text { elektronika }\end{array}$ \\
\hline & & $\begin{array}{l}\text { Saya mahir merakit } \\
\text { rangkaian elektronika }\end{array}$ & 64,66 & - & $\begin{array}{l}\text { Mahir merakit } \\
\text { elektronika }\end{array}$ \\
\hline & & Saya senang bermain game & 84,66 & \multirow[t]{3}{*}{$83,10 \%$} & \multirow{3}{*}{$\begin{array}{l}\text { Sangat tertarik } \\
\text { bermain game }\end{array}$} \\
\hline & & $\begin{array}{l}\text { Saya senang bermain game } \\
\text { simulasi }\end{array}$ & 84,00 & & \\
\hline & & $\begin{array}{c}\text { Saya senang bermain game } \\
\text { edukasi }\end{array}$ & 80,66 & & \\
\hline \multirow[t]{6}{*}{2} & \multirow[t]{6}{*}{$\begin{array}{l}\text { Interaksi } \\
\text { dengan } \\
\text { User } \\
\text { Interface }\end{array}$} & $\begin{array}{c}\text { Saya dapat mengenali } \\
\text { komponen-komponen } \\
\text { elektronika yang ada dalam } \\
\text { game }\end{array}$ & 81,33 & \multirow[t]{6}{*}{$77,88 \%$} & \multirow[t]{6}{*}{ Sesuai } \\
\hline & & $\begin{array}{c}\text { Saya mudah menggunakan } \\
\text { fitur-fitur yang disajikan di } \\
\text { dalam game }\end{array}$ & 82,00 & & \\
\hline & & $\begin{array}{l}\text { Saya mengerti informasi } \\
\text { yang disajika di dalam } \\
\text { game (menu tutorial dan } \\
\text { cara bermain) }\end{array}$ & 81,33 & & \\
\hline & & $\begin{array}{l}\text { Saya mengerti tugas yang } \\
\text { harus dilakukan dan } \\
\text { diselesaikan yang ada di } \\
\text { dalam game }\end{array}$ & 77,33 & & \\
\hline & & $\begin{array}{c}\text { Saya mudah menggerakan } \\
\text { objek }\end{array}$ & 76,00 & & \\
\hline & & $\begin{array}{c}\text { Saya mudah menggunakan } \\
\text { controller buatan untuk } \\
\text { teknologi Augmented } \\
\text { Reality }\end{array}$ & 69,33 & & \\
\hline \multirow[t]{3}{*}{3} & \multirow[t]{3}{*}{$\begin{array}{c}\text { User } \\
\text { Experience }\end{array}$} & $\begin{array}{l}\text { Saya merasakan game } \\
\text { simulasi ini seperti } \\
\text { praktikum di kelas }\end{array}$ & 52,66 & \multirow[t]{3}{*}{$58,66 \%$} & \multirow[t]{3}{*}{ Sesuai } \\
\hline & & $\begin{array}{l}\text { Saya merasakan kesulitan } \\
\text { yang sama seperti perakitan } \\
\text { rangkaian pada modul }\end{array}$ & 59,33 & & \\
\hline & & $\begin{array}{c}\text { Saya memahami simulasi } \\
\text { perakitan ketika } \\
\text { menyelesaikan satu stage }\end{array}$ & 64,00 & & \\
\hline \multirow[t]{2}{*}{4} & \multirow[t]{2}{*}{$\begin{array}{c}\text { Simulasi } \\
\text { dan edukasi }\end{array}$} & $\begin{array}{l}\text { Simulasi perakitan } \\
\text { rangkaian elektronika yang } \\
\text { tersedia dalam game dapat } \\
\text { disampaikan dengan baik }\end{array}$ & 80,66 & \multirow[t]{2}{*}{$80,66 \%$} & \multirow[t]{2}{*}{ Sangat Sesuai } \\
\hline & & $\begin{array}{c}\text { Dengan adanya media } \\
\text { game simulasi ini saya } \\
\text { dapat melakukan perakitan } \\
\text { elektronika tanpa }\end{array}$ & 86,66 & & \\
\hline
\end{tabular}




\begin{tabular}{|c|c|c|c|c|c|}
\hline No & $\begin{array}{c}\text { Aspek } \\
\text { Penilaian }\end{array}$ & Pertanyaan & Skor & Rata-rata & Kriteria \\
\hline & & $\begin{array}{c}\text { menggunakan komponen } \\
\text { asli }\end{array}$ & & & \\
\hline & & $\begin{array}{l}\text { Setelah melakukan simulasi } \\
\text { pada game saya merasa } \\
\text { dapat mencoba merakit } \\
\text { rangkian secara langsung }\end{array}$ & 74,66 & & \\
\hline \multirow[t]{4}{*}{5} & \multirow[t]{4}{*}{ Ujian } & $\begin{array}{l}\text { Bisa anda sebutkan ada } \\
\text { berapa total warna cincin } \\
\text { pada komponen resistor? }\end{array}$ & 86,66 & \multirow[t]{4}{*}{$79,16 \%$} & \\
\hline & & $\begin{array}{l}\text { Bisa anda sebutkan warna } \\
\text { apa saja untuk menunjukan } \\
\text { nilai } 10.5 \mathrm{k} \Omega \text { ? }\end{array}$ & 73,33 & & \\
\hline & & $\begin{array}{l}\text { Bisa anda gambarkan } \\
\text { rangkaian seri dengan } \\
\text { menggunakan LED? }\end{array}$ & 76,66 & & \\
\hline & & $\begin{array}{l}\text { Bisa anda gambarkan } \\
\text { rangkaian campuran tanpa } \\
\text { menggunakan LED? }\end{array}$ & 80,00 & & \\
\hline
\end{tabular}

Pada Tabel 2 menunjukkan hasil perhitungan tanggapan responden terhadap kuesioner berdasarkan game yang telah dibuat. Hasil tanggapan responden menujukkan bahwa game simulasi yang dirancang dengan menggunakan pendekatan Design Thinking.

Tabel 3. Hasil Perhitungan Kuesioner Mengenai Materi

\begin{tabular}{|c|c|c|}
\hline Pertanyaan & Jawaban Benar (\%) & Jawaban Salah (\%) \\
\hline Pertanyaan 1 & $86,66 \%$ & $13,34 \%$ \\
\hline Pertanyaan 2 & $73,33 \%$ & $26,67 \%$ \\
\hline Pertanyaan 3 & $76,66 \%$ & $23,34 \%$ \\
\hline Pertanyaan 4 & $80,00 \%$ & $20,00 \%$ \\
\hline Rata-Rata & $\mathbf{7 9 , 1 6 \%}$ & $\mathbf{2 0 , 8 4 \%}$ \\
\hline
\end{tabular}

Berdasarkan Tabel 3, dapat dilihat hasil pemahaman 30 responden berdasarkan pertanyaan ujian setelah memainkan game ELECTAR, pertanyaan ini dibuat untuk mendapatkan data pemahaman responden yang telah memainkan game ELECTAR terhadap mata pelajaran Elektronika Dasar pertanyaan ini berhasil dijawab dengan rata-rata sebanyak $79,16 \%$ dengan benar oleh para responden sehingga bisa disebutkan bahwa game yang dibangun telah berhasil mensimulasikan perakitan rangkaian Elektronika Dasar.

\section{KESIMPULAN}

Penelitian ini telah menghasilkan sebuah game simulasi untuk perakitan rangkaian elektronika dasar untuk siswa kelas X Sekolah Menengah Kejuruan dengan pendekatan Design Thinking. Game yang dibangun dapat menyajikan sebuah simulasi perakitan rangkaian sederhana dengan teknologi Mobile Augmented Reality untuk menampilkan objek komponen. Game dibuat sebisa mungkin mendapatakan User Experience yang sama seperti kegiatan nyata untuk merakit rangkaian elektronika dasar.

Game telah diuji kepada 30 orang responden siswa SMK kelas X dengan mencoba memainkan game simulasi ini. Pada aspek latar belakang para responden memiliki rasa tertarik pada 
elektronika memiliki skor sebesar $80 \%$ tetapi pada keseluruhan siswa yang mahir dalam elektronika hanya sebesar $64,66 \%$. Untuk aspek ketertarikan responden terhadap game simulasi dan edukasi adalah sebesar $83,10 \%$. Game ini telah dibangun dengan pendekatan Design Thinking dimana hasil untuk responden terhadap User Interface yang sudah dibangun adalah sebesar $77,88 \%$ dengan hasil responden didukung pada bagian fitur-fitur pada game yang mudah digunakan dengan skor $82 \%$, hasil untuk capaian User Experience terhadap cara bermain yang disajikan hanya mencapai $58,66 \%$ hal ini berkaitan dengan aspek yang disajikan hanya dipahami responden dengan skor 64\%, untuk aspek simulasi dan edukasi dicapai sebesar $81,86 \%$ oleh para responden dan terakhir pertanyaan berhasil dijawab sebanyak $79,16 \%$ dengan benar oleh para responden.

\section{UCAPAN TERIMA KASIH}

Penulis mengucapkan terima kasih kepada para rekan penulis yang telah membantu dalam percarian data dan memberikan dukungan untuk menyelesaikan penelitian ini. Dan juga terima kasih kepada para responden atas ketersediaan waktunya untuk menguji coba game yang telah dibuat dan mengisi kuesioner yang telah disediakan.

\section{DAFTAR RUJUKAN}

[1] A. A. Wijaya, S. Bukhori, dan N. Oktavia, "Perancangan dan Pembuatan Serious Game Sebagai Simulasi Aktivitas Bisnis dan Akuntansi Menggunakan Pendekatan Agent-Based Modelling," Berkala Saintek, vol. 2, hal. 66-75, 2017.

[2] A. V. Vitianingsih, "Game Edukasi Berbasis Android Sebagai Media Pembelajaran Untuk Anak Usia Dini," vol. 1, no. 1, hal. 46-58, 2016.

[3] N. I. Widiastuti dan I. Setiawan, "Membangun Game Edukasi Sejarah Walisongo," Jurnal IImiah Komputer dan Informatika (KOMPUTA), vol. 1, no. 2, hal. 41-48, 2012.

[4] R. P. Santoso, "Pembelajaran dengan Menggunakan Media Game Simulasi Artikel Ilmiah," 2016.

[5] F. P. Suprobo, "Penerapan Design Thinking dalam Inovasi Pembelajaran Desain dan Arsitektur," hal. 509-517, 2012.

[6] S. Nebel, S. Schneider, J. Schledjewski, dan G. D. Rey, "Goal-Setting in Educational Video Games: Comparing Goal-Setting Theory and the Goal-Free Effect," Simulation and Gaming, vol. 48, no. 1, hal. 98-130, 2017.

[7] W. C. Kriz, "Types of Gaming Simulation Applications," Simulation and Gaming, vol. 48, no. 1, hal. 3-7, 2017.

[8] A. Z. Rahman, T. N. Hidayat, dan I. Yanuttama, "Media Pembelajaran IPA Kelas 3 Sekolah Dasar Menggunakan Teknologi Augmented Reality Berbasis Android," hal. 43-48, 2017.

[9] W. Trooster, "The Use of Virtual Worlds and Serious Gaming in Education," Simulation, Serious Games and Their Applications, hal. 121-126, 2014.

[10] K. L. McGlarty et al., "A Literature Review of Gaming in Education Research Report," Gaming in education, no. June, hal. 1-36, 2012.

[11] Yohandri dan Asrizal, Elektronika Dasar 1, Edisi Pert. Jakarta: Kencana, 2016.

[12] L. Barnett, C. Harvey, dan C. Gatzidis, "First Time User Experiences in mobile games: An evaluation of usability," Entertainment Computing, vol. 27, hal. 82-88, 2018.

[13] K. Thoring dan R. Müller, "Creating Knowledge in Design Thinking the Relationship of Process Steps and Knowledge Types," International Association of Societies of Design Research, hal. 1-9, 2011.

[14] Kurniawan T. Martono, "Augmented Reality sebagai Metafora Baru dalam Teknologi Interaksi Manusia dan Komputer," Jurnal Sistem Komputer, vol. 1, no. 2, hal. 60-64, 2011. 
[15] T. Rahmawati, "Perancangan Augmented Reality Volcano untuk Alat Peraga Museum," Teknomatika, vol. 5, hal. 1-11, 2013.

[16] D. I. S. Saputra, E. Utami, dan A. Sunyoto, "Penerapan Mobile Augmented Reality Berbasis Cloud Computing pada Harian Umum Radar Banyumas," Seminar Nasional Informatika 2013, hal. B14-B21, 2013.

[17] Sugiyono, Metode Penelitian Kuantitiatif, Kualitatif dan R\&D. Bandung: Alfabeta, 2010. 